\title{
Comparative Study on Fatigue Behavior of K and K-T Steel Truss Joints
}

\author{
Akhil V Raj ${ }^{1}$, Anup Joy ${ }^{2}$ \\ ${ }^{1}$ P G Scholar, Department of Civil Engineering (Structural Engineering), Sree Buddha College of Engineering, Pattoor, Alappuzha, Kerala \\ ${ }^{2}$ Assistant Professor, Department of Civil Engineering (Structural Engineering), \\ Sree Buddha College of Engineering, Pattoor, Alappuzha, Kerala
}

\begin{abstract}
Steel girders and its various forms are now a day's used in the building and bridge constructions. Steel girders have minimal cost of construction and high degree of efficiency. They are especially suitable for large-span structures and for greater load transfer in building construction as well as bridge construction Steel girder transfer their loads to one member to another through its joints. So the joints are most important portion of a truss girder. In this work, modeling of each joint was carried out by using finite element method and software ANSYS-2016 to evaluate and compare the ultimate strength and fatigue behavior of $K$ and $K-T$ truss joints. $K$ and $K-T$ joints are mostly appeared in a truss girder. For getting the maximum efficiency and performance, in this study, composite joints were analyzed.
\end{abstract}

Keywords: composite joints, deflection, fatigue strength, von Misses stress

\section{Introduction}

Steel and concrete composite structures have been extensively applied in bridge constructions due to the benefits of combining two different constructional materials. Reinforced concrete is in general inexpensive, massive and stiff, whilst steel is relatively strong, lightweight and easy to assemble. Composite concept with the main objective to find innovative structures to make the bridges cost competitive has been promoted. For getting the maximum efficient and performed structures steel girders with composite behavior are used. Joints are the most important portions of a steel girder structures. Joints will transfer the total loads to the other members. By making composite joints the performance of the joints will increase. For the structures like steel bridges and marine sub and super structures will damaged due to the continuous stress reversal by external forces. In such a case the performance of the structures will decided by the joints and their effectiveness. For getting the maximum effectiveness composite joints were used. $\mathrm{K}$ and $\mathrm{K} \mathrm{T}$ type steel girder joints were found more common in steel girder structures. Their fatigue behavior will decide the efficiency of the composite joints. There are several ways for the truss girder joint failures likeplastic failure of the chord crosssection,Chord side wall failure by yielding, crushing, Chords shear failure, punching shear of hollow section chord wall. Brace failure with reduced effective width under crack in the welds or in the brace member.Local buckling failure of the brace member.

\section{Scope of study}

- The results from finite element analysis using ANSYS will provide reference for design and construction of joints in steel truss girder works.

- To develop finite element models that accurately predict accepted theoretical capacities of hollow, concrete filled tubular and additionally reinforced tubular $\mathrm{K}$ and $\mathrm{K}-\mathrm{T}$ joints of truss girder.
- Results can be used for the future development and further construction of the marine and harbour structures

\section{Objective of study}

- Investigating the effects of filled concrete and additional reinforcement on the ultimate load of truss girder $\mathrm{K}$ and $\mathrm{K}$ $-\mathrm{T}$ steel girder joint.

- To find the best composition of K and K-T joint for good strength and long life.

- Validation of experimental study paper on steel truss girder joints in ANSYS software.

- Compare the ultimate strength and fatigue behaviour of concrete filled and additionally reinforced tubular $\mathrm{K}$ and $\mathrm{KT}$ joints of truss girder.

\section{ANSYS Software}

ANSYS software is a comprehensive FEA analysis (Finite element) tool for structural analysis, including linear, nonlinear and dynamic studies. ANSYS software allows engineers to construct computer models of structures, machine components or systems; apply operating loads and other design criteria; and study physical responses, such as stress levels, temperature distributions, pressure, etc. It permits an evaluation of a design without having tobuild and destroy multiple prototypes in testing. The ANSYS program has a variety of design analysis applications, ranging from such everyday items as dishwashers, cookware, automobiles, running shoes and beverage cans to such highly sophisticated systems as aircraft, nuclear reactor containment buildings, bridges, farm machinery, X-ray equipment and orbiting satellites.

\section{Material Specifications}

a) Steel

- Young's Modulus E=2.1 x $10^{11} \mathrm{~N} / \mathrm{m}^{2}$

- Poison's ratio $\mathrm{v}=0.3$

Volume 5 Issue 6, June 2016 www.ijsr.net 


\section{International Journal of Science and Research (IJSR) \\ ISSN (Online): 2319-7064}

Index Copernicus Value (2013): 6.14 | Impact Factor (2015): 6.391

b) Concrete

- Young's Modulus E=3.19 x10 9 N/m2

- Poison's ratio $\mathrm{v}=0.2$

c) Meshes

- Mesh size $=20 \mathrm{~mm}$

- element solid 65 for concrete

- element shell185 for steel tubes simulation

\section{d) Boundary conditions}

For each of the two ends of diagonal members same types of boundary conditions were used. The displacement degrees of freedom in 1, 2, 3 directions (U1, U2, U3) as well as rotational degrees of freedom in 1, 2, 3 directions were restrained to be zero.

\section{e) Specimen geometry}

All modeling was conducted using ANSYS finite element software. The project proceeded in several stages of modeling; all specimens were modeled as 3D solid objects with identical geometry.A total of 6 specimens for $\mathrm{K}$ joint analysis and another 6 specimens for KT joint analysis were used for this study. The static test and the fatigue test are carried. The modeling is consists of creating key points, lines, volumes and areas, with same dimension given in the experimental data. Fig. 1 and Fig. 2 shows the geometry of the $\mathrm{K}$ and KT sections modeled. Tet-free meshing is done which has no restrictionsin terms of element shapes, and has no specified pattern applied to it.

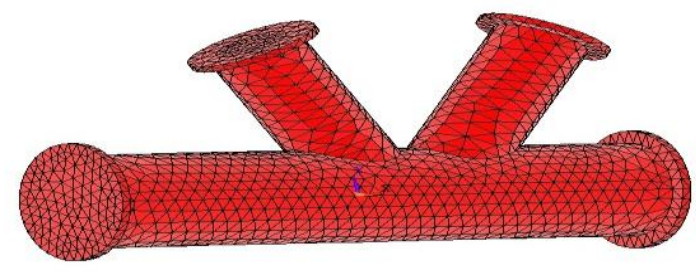

Figure 1: FEA K model-Schematic view with meshing

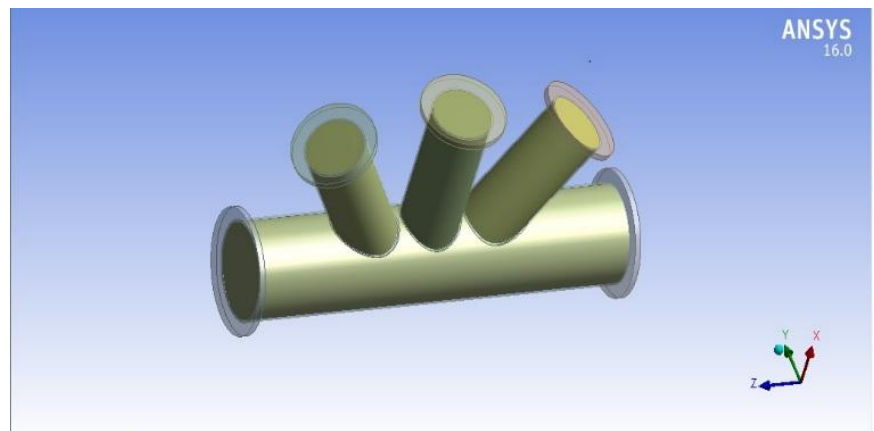

Figure. 2: FEA K-T model-Schematic view

\section{f) Modelling of specimen}

$\mathrm{K}$ \& K-T JOINTS-. Chord member diameterD $=318.5 \mathrm{~mm}$, Thickness $\mathrm{T}=6.9 \mathrm{~mm}$, Diagonal and $\mathrm{T}$ member diameter $\mathrm{D}=216.5 \mathrm{~mm}$, Thickness $\mathrm{T}=5.8 \mathrm{~mm}$, Six specimen were modelled for $\mathrm{K}$ joints and $\mathrm{KT}$ joints like $\mathrm{K} 1, \mathrm{~K} 2, \mathrm{~K} 3, \mathrm{~A} 1, \mathrm{~A} 2, \mathrm{~A} 3 \quad$ and $\mathrm{KT} 1, \mathrm{KT} 2, \mathrm{KT} 3, \mathrm{~B} 1, \mathrm{~B} 2, \mathrm{~B} 3$ respectively.

\section{Analysis}

\section{- Static analysis of K1 and KT1 specimen}

$\mathrm{K} 1$ specimen is a circular hollow tube with a chord and two diagonal members. The specimen takes ultimate load up to $570 \mathrm{kN}$ and there after it fails. KT1 specimen is also a circular hollow tube with a tee member in addition to diagonal members. The specimen fails at $1500 \mathrm{kN}$. Von Misses and displacement of the members due to the failure loads is shown in the Fig.3, Fig.4, Fig.5 and Fig 6.

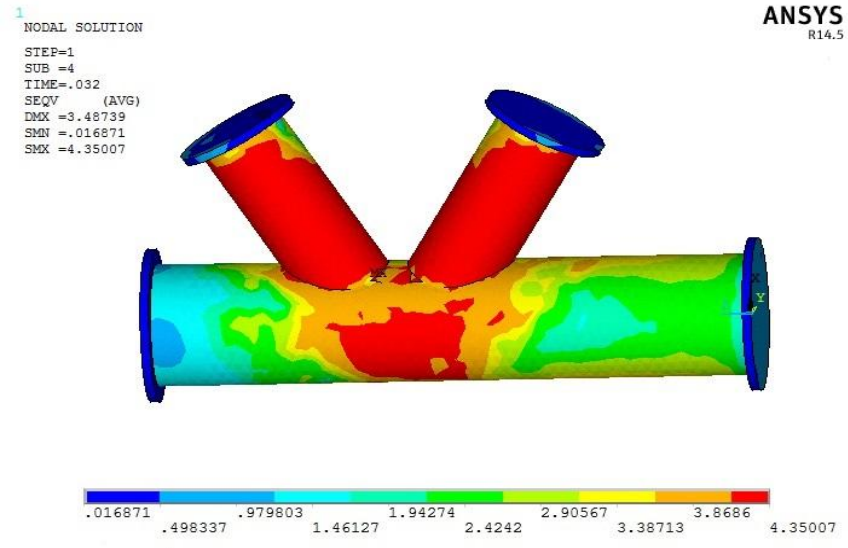

Figure 3: Von misses stress diagram of $\mathrm{K} 1$

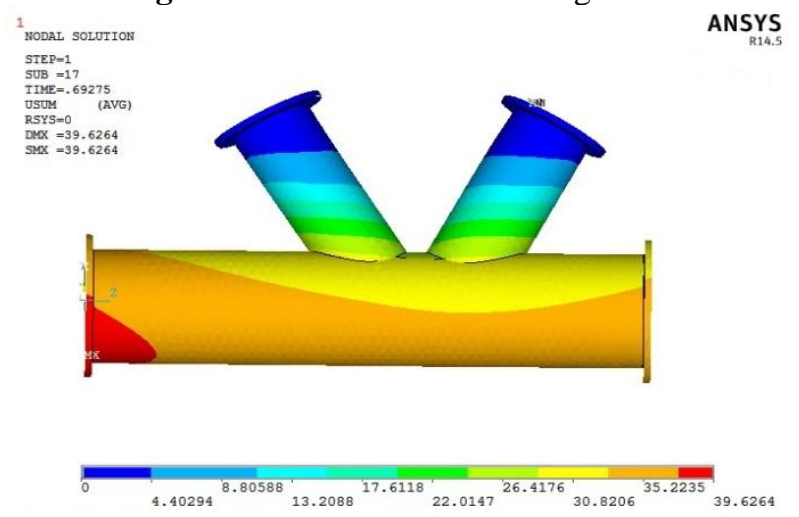

Figure 4:Displacement diagram of K1

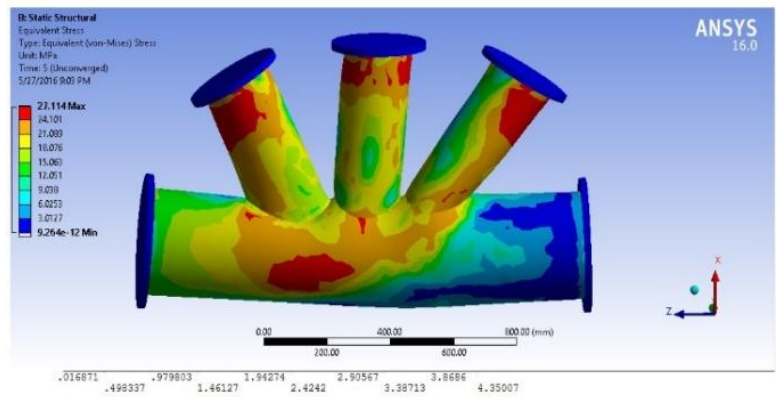

Figure 5: Von misses stress diagram of KT1

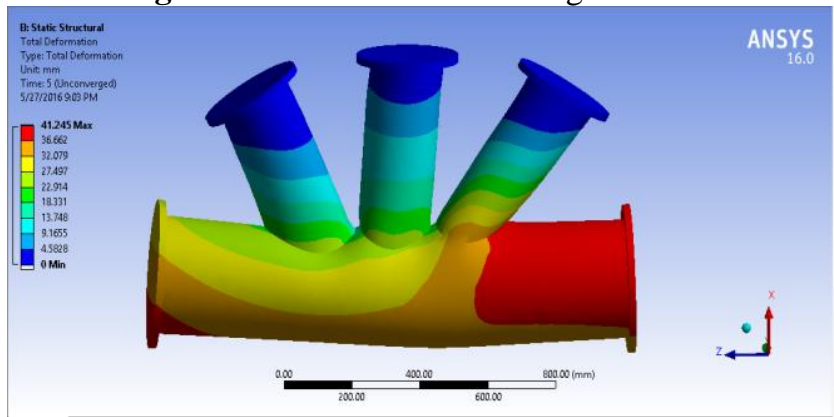

Figure 6:Displacement diagram of KT1

Volume 5 Issue 6, June 2016 www.ijsr.net 


\section{International Journal of Science and Research (IJSR) \\ ISSN (Online): 2319-7064 \\ Index Copernicus Value (2013): 6.14 | Impact Factor (2015): 6.391}

For $\mathrm{K}$ joint, Maximum stress $=4.35 \mathrm{~N} / \mathrm{mm}^{2}$ and displacement $=39.62 \mathrm{~mm}$. Similarly for KT joint maximum stress $=27.11 \mathrm{~N} / \mathrm{mm}^{2}$ and displacement $=41.24 \mathrm{~mm}$

\section{- Static analysis of K2 and KT2}

In this specimen concrete is filled in chord member and the deformation of the chord wall is restricted by concrete, thus the strength of the joint was improved for K2 and KT2 joint. The von misses stress diagram and displacement diagrams of $\mathrm{K} 2$ and KT2 at ultimate load $1200 \mathrm{kN}$ and $3000 \mathrm{kN}$ respectively is shown in Fig.5.5, Fig.5.6, Fig.5.7 and Fig.5.8. Maximum stress $=131.66 \mathrm{~N} / \mathrm{mm}^{2}$ and displacement $=3.47$ $\mathrm{mm}$. Similarly for KT joint maximum stress $=73.11 \mathrm{~N} / \mathrm{mm}^{2}$ and displacement $=198.36 \mathrm{~mm}$

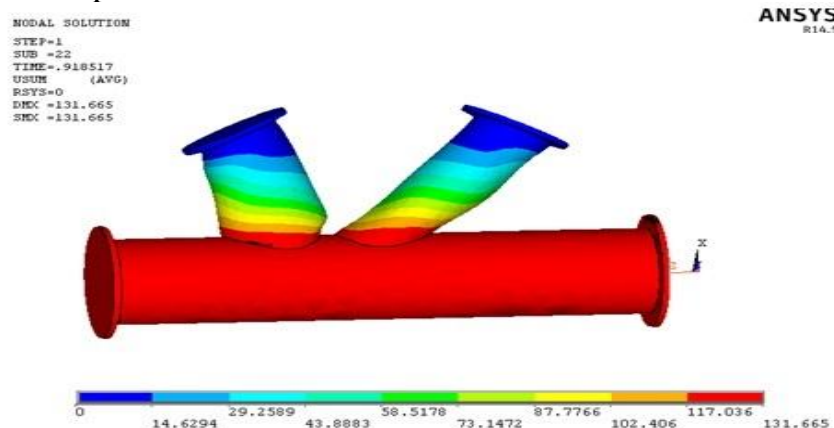

Figure 7: Von misses stress diagram of K2
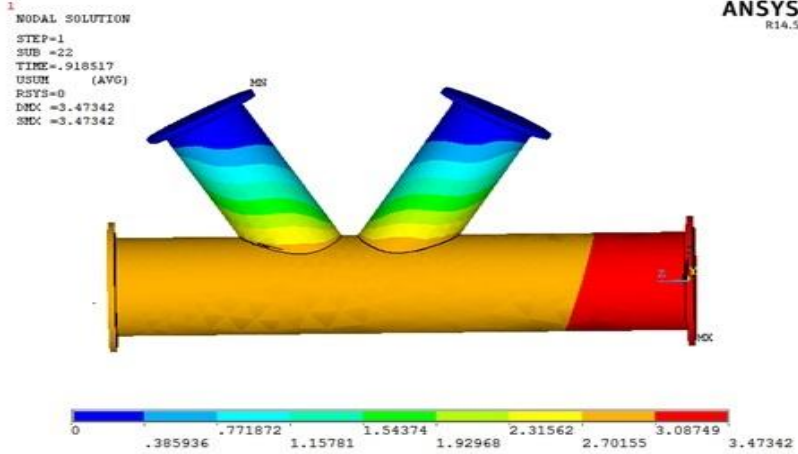

Figure 8:Displacement diagram of $\mathrm{K} 2$

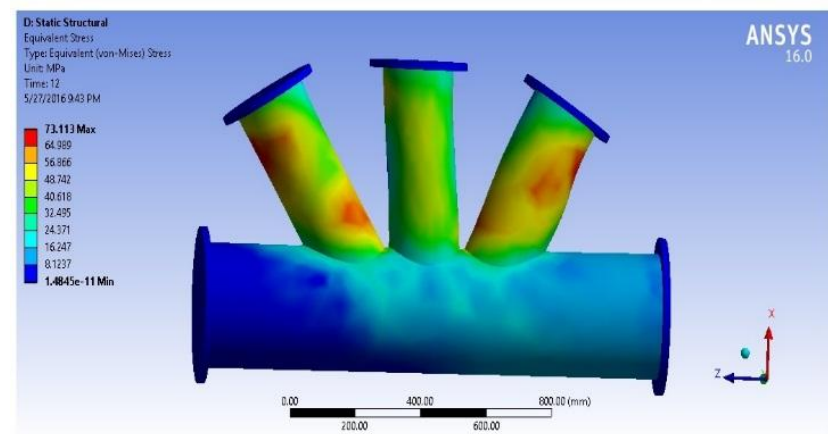

Figure 9: Von misses stress diagram of KT2

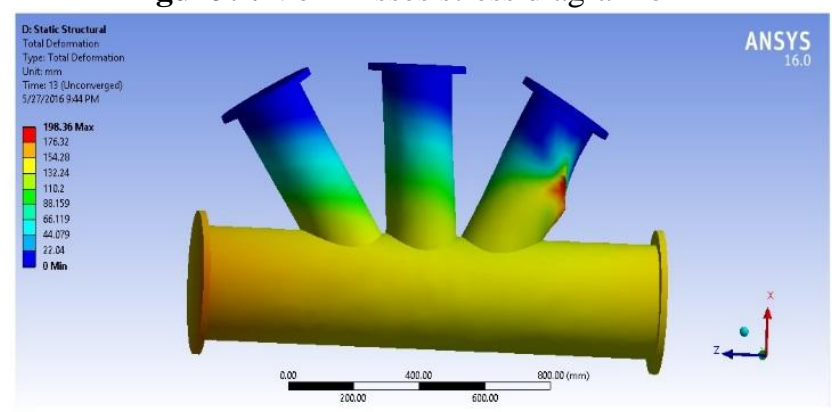

Figure 10:Displacement diagram of KT2
- Static analysis of K3 and KT3 specimen

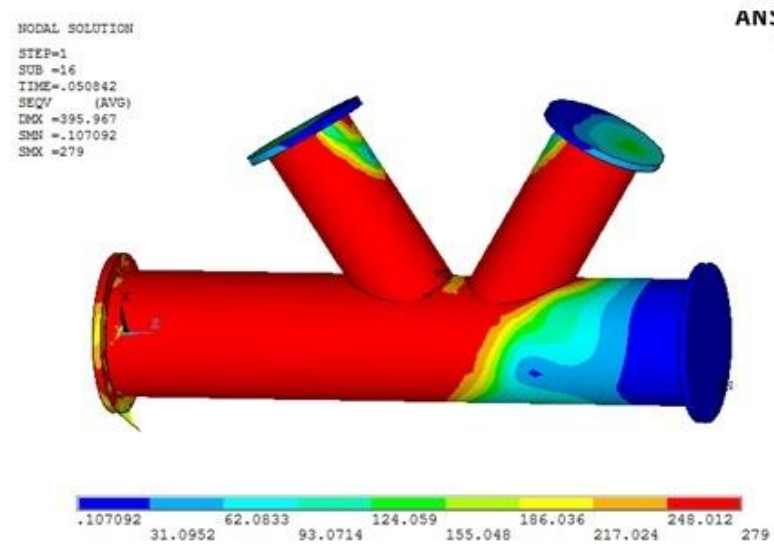

Figure 11: Von misses stress diagram of $\mathrm{K} 3$

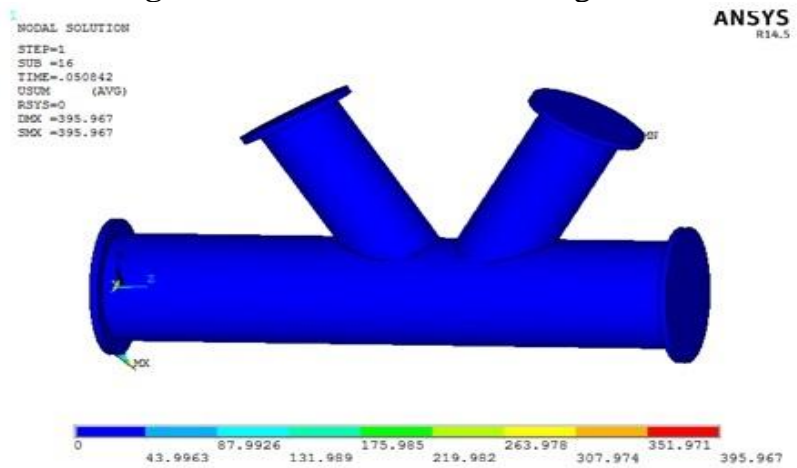

Figure 12:Displacement diagram of K3

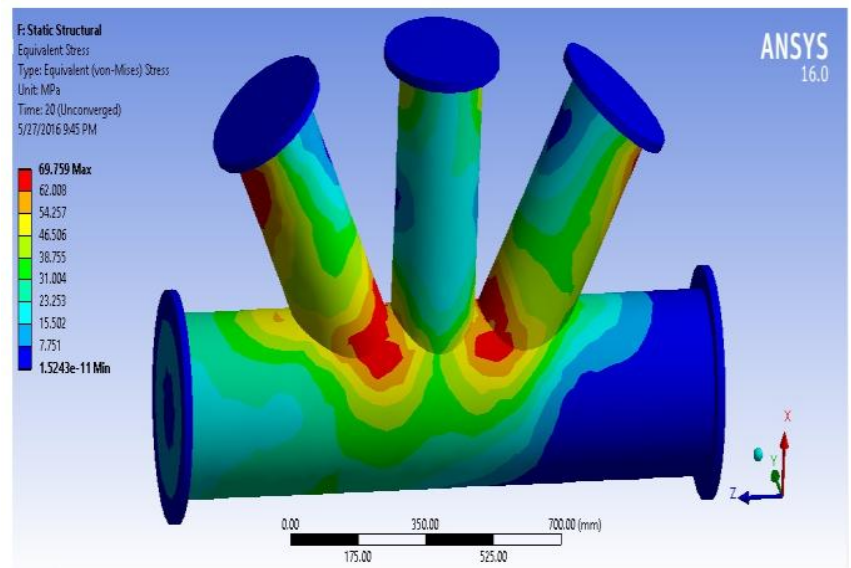

Figure 13: Von misses stress diagram of KT3

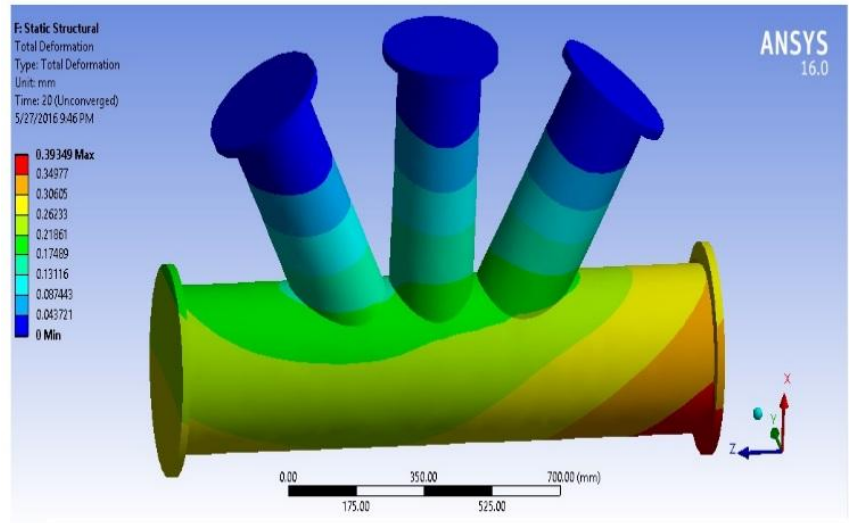

Figure 14:Displacement diagram of KT3

Volume 5 Issue 6, June 2016 www.ijsr.net 


\section{International Journal of Science and Research (IJSR) \\ ISSN (Online): 2319-7064}

Index Copernicus Value (2013): 6.14 | Impact Factor (2015): 6.391

\section{- Static analysis of A1 and B1 specimen}

This specimen filled with concrete both in chord diagonal and tee members and reinforced by dowels in one row, which connect with holes in a chord member and diagonal members. Stud is having diameter of $3 \mathrm{~mm}$ and length $60 \mathrm{~mm}$. The ultimate load obtained is $3400 \mathrm{kN}$ and $6000 \mathrm{kN}$ and is 5.96 times greater than K1 joint and 6 times for KT1 joint. The von misses stress diagram and deflection is shown in Fig.5.13, Fig.5.14, Fig.5.15 and Fig.5.16 respectively. For $\mathrm{K}$ joint, Maximum stress $=521.21 \mathrm{~N} / \mathrm{mm}^{2}$ and displacement $=$ $2.69 \mathrm{~mm}$. Similarly for KT joint maximum stress $=94.93$ $\mathrm{N} / \mathrm{mm}^{2}$ and displacement $=5.83 \mathrm{~mm}$

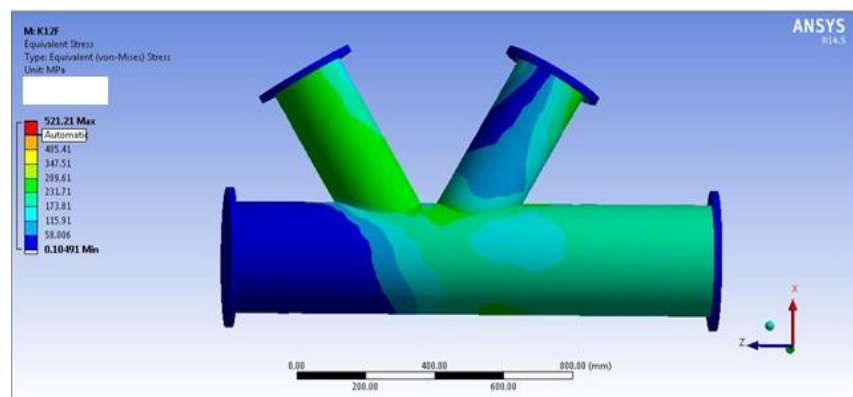

Figure 15: Von misses stress diagram of A1

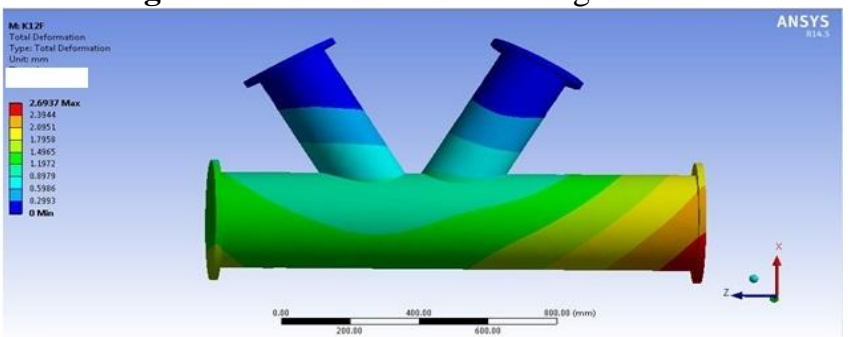

Figure 16:Displacement diagram of A1

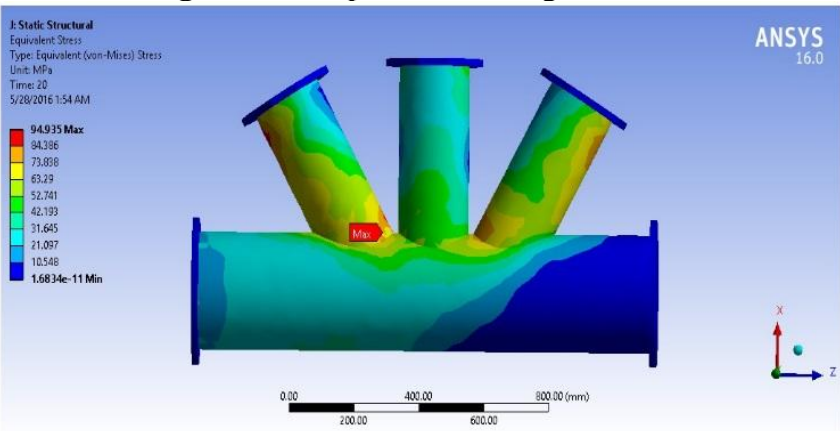

Figure 17: Von misses stress diagram of B1

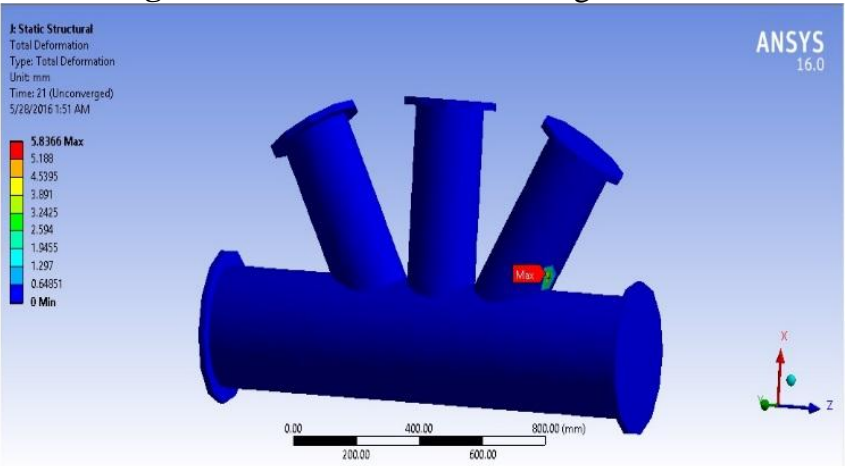

Figure 18:Displacement diagram of B1

\section{- Static analysis of A2 and B2 specimen}

Specimen A2 and B2 is filled with concrete both in chord and diagonal members and reinforced by dowels in chord member.The ultimate load obtained is $\mathbf{5 . 1 6}$ times greater than K1 and KT1 joint. The von misses stress diagram and displacement diagram is shown in Fig.5.17, Fig.5.18, Fig.5.19 and Fig.5.20.For K joint, Maximum stress = 521.21 $\mathrm{N} / \mathrm{mm}^{2}$ and displacement $=2.69 \mathrm{~mm}$. Similarly for KT joint maximum stress $=94.93 \mathrm{~N} / \mathrm{mm}^{2}$ and displacement $=5.83 \mathrm{~mm}$

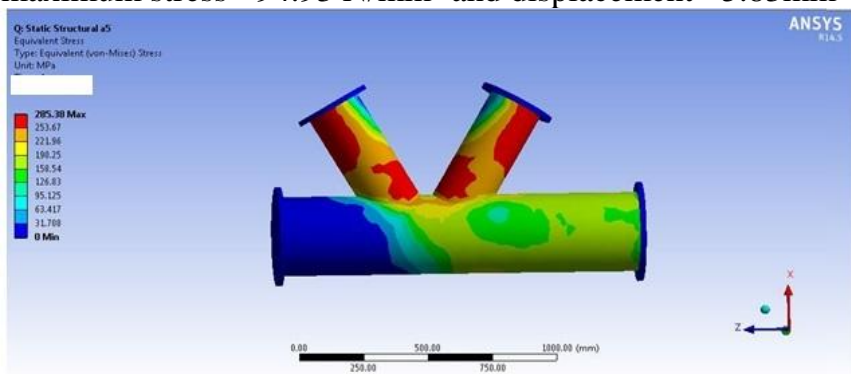

Figure 19: Von misses stress diagram of A2

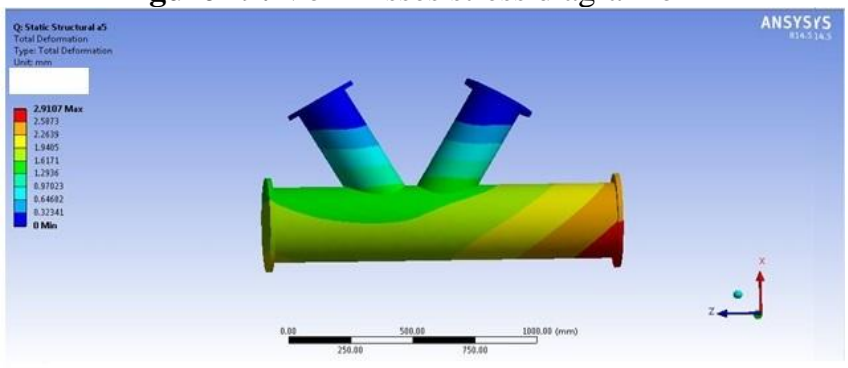

Figure 20:Displacement diagram of A2

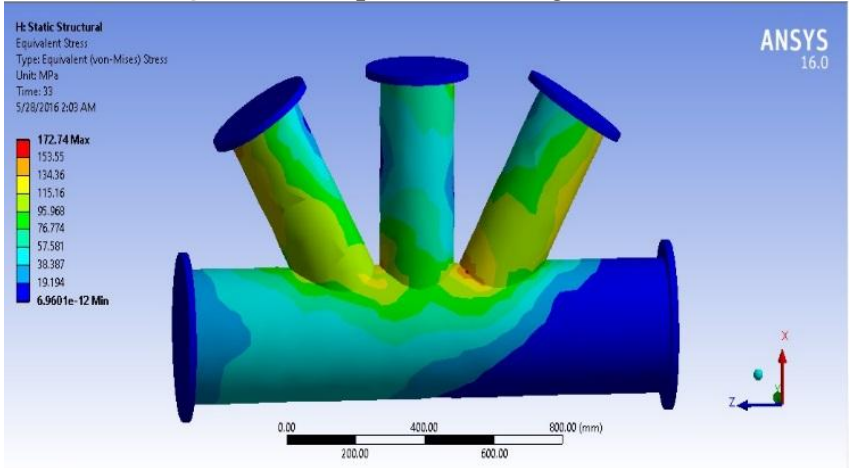

Figure 21: Von misses stress diagram of B2

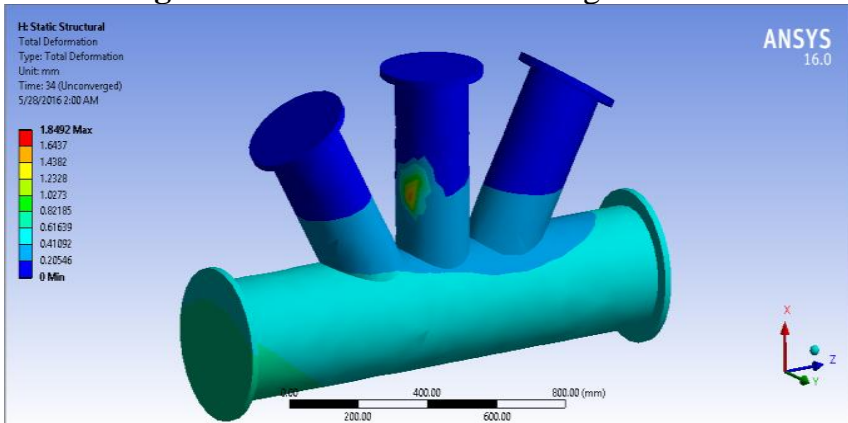

Figure 22:Displacement diagram of B2

Volume 5 Issue 6, June 2016 www.ijsr.net 


\section{International Journal of Science and Research (IJSR) \\ ISSN (Online): 2319-7064}

Index Copernicus Value (2013): 6.14 | Impact Factor (2015): 6.391

- Static analysis of A3 and B3 specimen

Specimen A3 had a gusset, and is composed of filled concrete both in chord and diagonal members. The gusset plate is having a size of $240 \mathrm{~mm}$ at diagonal member side and thickness of $5.8 \mathrm{~mm}$. B3 filled concrete in both chord, diagonal and $\mathrm{T}$ member and reinforced by dowels in two row in chord, diagonal and $\mathrm{T}$ member. The results are given below. For $\mathrm{K}$ joint, Maximum stress $=279 \mathrm{~N} / \mathrm{mm}^{2}$ and displacement $=36.33 \mathrm{~mm}$. Similarly for KT joint maximum stress $=395.3 \mathrm{~N} / \mathrm{mm}^{2}$ and displacement $=3.4 \mathrm{~mm}$

\section{Comparison of Static Analysis Results}

Ultimate load and stress of the six $\mathrm{K}$ joints were summarized in Fig.6.1 and Fig.6.2 and Ultimate load and stress of the six KT joints were summarized in Fig.6.3 and Fig.6.4.

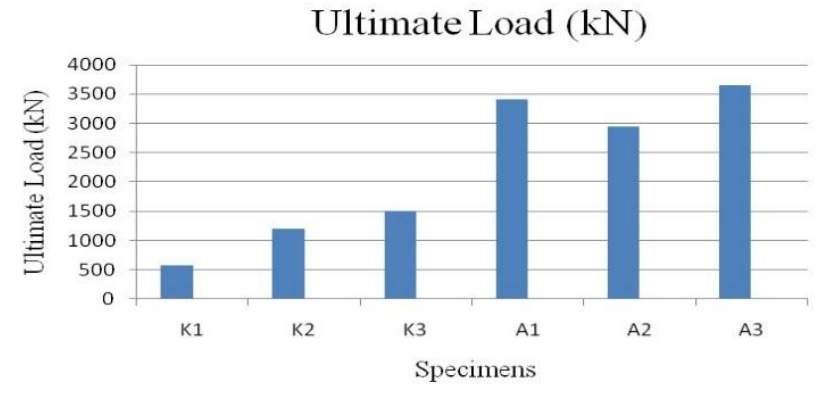

Figure 23: Ultimate load of $\mathrm{K}$ joint specimens

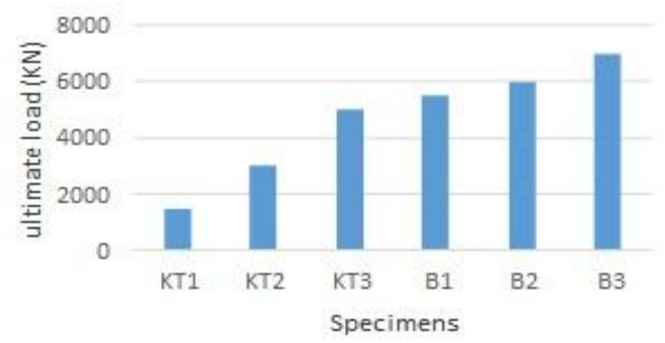

Figure 25: Ultimate load of K-T joint specimens

\section{Fatigue Analysis}

Fatigue analysis were done on A1, A2 and A3and B1, B2 and B3 specimens results are shown in the Table 1

Table 1: Comparitive results of fatigue analysis

\begin{tabular}{|c|c|c|}
\hline Specimen & Ultimate load(kN) & Minimu life(cycles) \\
\hline A1 & 3400 & 104879 \\
\hline A2 & 2939 & 101704 \\
\hline A3 & 3650 & 174500 \\
\hline B1 & 5500 & 214525 \\
\hline B2 & 6000 & 225252 \\
\hline B3 & 7000 & 253211 \\
\hline
\end{tabular}

\section{Conclusion}

- Ultimate loads of specimens are increased as their reinforcements are increased and the lowest ultimate load is obtained for hollow specimens for both the $\mathrm{K}$ and $\mathrm{K}-\mathrm{T}$ joints.

- The specimen filled concrete with dowels, and the specimen filled concrete with a gusset have the highest ultimate load.
- Filled concrete in chord member improves the ultimate load carrying capacity by resisting deformations.

- Composite truss girder joint construction proves to be an efficient system by providing reinforcement within the joint that distributes the stresses.

- Comparatively K-T joints shows more fatigue strength and this joint is advisable for upcoming marine structures.

\section{References}

[1] Wenjin Huang, Luigi Fenu, Baochun Chen, Bruno Briseghella, "Experimental study on $K$-joints of concrete-filled steel tubular truss structures", Journal of Constructional Steel Research, Vol.107, PP 182-193, (February 2015).

[2] ZHENG Shang-mln, WAN Shul, "Finite element analysis of shear lag effect on composite girder with steel truss webs", Journal on High way and transportation research and development, Vol. 8, PP 8993, (2014).

[3] Lanying Zhu, Zhijun Wang, Mengli Song, "Experimental study of steel truss girder with Z-shaped clips", Conf. on Advances In Civil, Structural and Environmental Engineering- ACSEE, PP-89-93, (2014).

[4] Joanna Jankowska, Sandberg, JarosławKołodziej, "Experimental study of steel truss lateral-torsional buckling", Journal of Engineering Structures, Vol.46, PP 165-172, (September 2013).

[5] YuqingLiu, HaohuiXin, Jun He, DongyanXue, Biao Ma,"Experimental and analytical study on fatigue behavior of composite truss joints", Journal of Constructional Steel Research, Vol.83, PP 21-36, (January 2013).

[6] DongyanXue, Yuqing Liu, Jun He, Biao Ma, "Experimental study and numerical analysis of a composite truss joint”, Journal of Constructional Steel Research, Vol.67,PP 957-964, (January 2011).

[7] Fidelis RutendoMashiri, Xiao-Ling Zhao, "Square hollow section (SHS) T-joints with concrete-filled chords subjected to in-plane fatigue loading in the brace", Journal of Thin-Walled Structures, PP-150-158, (October 2009).

[8] Scott Walbridgea, Alain Nussbaumer, "Probabilistic fatigue analysis of shop and field treated tubular truss bridges", Journal of Constructional Steel Research, PP156-166, (June 2008).

[9] Yong-Bo Shao, "Analysis of stress intensity factor (SIF) for cracked tubular K-joints subjected to balanced axial load', Journal of Engineering Failure Analysis, Vol.13, PP44-64, (March 2006).

[10] Yoshinaga Sakai ,Tetsuya Hosaka b, Akira Isoe ,Atsushi Ichikawa, Kaoru Mitsuki, "Experiments on Concrete Filled And Reinforced Tubular K-Joints Of Truss Girder", Journal of Constructional Steel Research, Vol.60 ,PP 683-699, (May 2004).

[11]R.H. Wang, Q.S. Li , Q.Z. Luo, J. Tang, H.B. Xiao, Y.Q. Huang, "Nonlinear analysis of plate-truss composite steel girders", Journal of Engineering Structures, Vol.25, PP 1377-1385, (April 2003). 